\title{
Further studies of the effects of follicular fluid and membrana granulosa cells on the spontaneous maturation of pig oocytes
}

\author{
Catherine Racowsky* and R. W. McGaughey \\ Department of Zoology, Arizona State University, Tempe, Arizona 85287, U.S.A.
}

\begin{abstract}
Summary. Liberated cumulus-enclosed pig oocytes were cultured either alone in follicular fluid or with membrana granulosa cells in a complex serum based medium. After $24 \mathrm{~h}$, oocytes were air-dried for cytogenetic analysis, meiotic stage was scored, and viability of granulosa cells was determined. Neither the release from meiotic arrest nor the progression of maturation to metaphase II was significantly inhibited by either of these follicular components. Co-culture of membrana granulosa cells and oocytes significantly stimulated maturation in one experimental series, while viability of the somatic cells was maintained in all experiments. These results do not support the concept of a stable oocyte maturation inhibitor of granulosa cell origin in follicular fluid.
\end{abstract}

\section{Introduction}

Pincus \& Enzmann (1935) originally observed, and others have since confirmed (reviewed by Tsafriri, 1979; Channing, Schaerf, Anderson \& Tsafriri, 1980), that intact, immature mammalian oocytes will spontaneously mature in culture when removed from their follicular environment. This observation has led to the hypothesis that the immature follicle synthesizes a maturation inhibitor, the effect of which is overridden upon exposure of the follicle to $\mathrm{LH}$ (reviewed by Tsafriri, 1979). Although considerable effort has been made to elucidate the factor(s) responsible for this follicular regulation, neither the origin nor the nature of this inhibitor have been established definitively. Several reports, however, have suggested a membrana granulosa cell origin (reviewed by Tsafriri, 1979) and have claimed that the inhibitor is a peptide of low molecular weight (Tsafriri, Channing, Pomerantz \& Lindner, 1977; Stone, Pomerantz Schwartz-Kripner \& Channing, 1978), oestradiol (McGaughey, 1977a; Richter \& McGaughey, 1979; Rice \& McGaughey, 1981) or cyclic adenosine monophosphate (Cho, Stern \& Biggers, 1974; Dekel \& Beers, 1978).

In recent years, attention has been focussed particularly upon a small peptide, called oocyte maturation inhibitor (OMI), which was originally ascribed such an inhibitory function by Tsafriri \& Channing (1975a). Since co-culture of con-specific membrana granulosa cells with porcine (Tsafriri \& Channing, 1975a) or rat (Tsafriri, 1978) oocytes resulted in maintenance of meiotic arrest, it has been suggested that OMI is synthesized by these somatic cells and is released into follicular fluid (Tsafriri, Pomerantz \& Channing, 1976a, b). Indeed, granulosa cell extracts (Tsafriri et al.. 1976a), media in which granulosa cells have been cultured (Tsafriri, 1978) and co-cultures of oocytes in the presence of, but not in contact with, follicular

* Formerly Rice. 
hemisections (Tsafriri \& Channing, 1975b) all resulted in inhibition of spontaneous maturation of pig oocytes. Furthermore, the presence of OMI activity has been reported in porcine follicular fluid (Tsafriri et al., 1976a; Stone et al., 1978), and this fluid has been demonstrated to inhibit the spontaneous maturation of pig (Tsafriri \& Channing, 1975a; Centola \& Anderson, 1979; Jagiello, Graffeo, Ducayen \& Prosser, 1977), mouse (Tsafriri, 1979) and rat (Tsafriri et al., 1977) oocytes.

Studies from several other laboratories, however, have failed to demonstrate such inhibitory activity of follicular components: co-culture of membrana granulosa cells did not inhibit the maturation of intact oocytes of mouse (Nekola \& Smith, 1974), pig (Jagiello et al., 1977; Rice \& McGaughey, 1980), cow (Jagiello et al., 1977; Leibfried \& First, 1980a) or ewe (Jagiello et al., 1977), and follicular fluid did not prevent resumption of meiosis of pig (Sato \& Ishibashi, 1977; McGaughey, 1978; Leibfried \& First, 1980a) or cow (Sreenan, 1970) oocytes. These conflicting data indicated a serious need to re-investigate the regulatory potential of follicular components on oocyte maturation. The results of such a re-investigation, using the pig oocyte in the bioassay, are reported in this paper.

\section{Materials and Methods}

\section{Collection of oocytes}

Reproductive tracts were obtained from a local abattoir within a few minutes of slaughter. The ovaries from 4 or more gilts provided oocytes for an individual experiment; selected oocytes from one ovary served as the controls for experimental oocytes from the contralateral ovary. Oocytes were routinely collected from medium-sized antral follicles $(3-5 \mathrm{~mm}$ diameter), by vigorously puncturing the ovary with a sterile 18 gauge needle, into BMOC-3 medium (Brinster, 1971) modified to contain dextran T-70 $(4.5 \mathrm{mg} / \mathrm{ml}$; Pharmacia) as described by McGaughey (1977b) (BMOC-2A). In one series of experiments (Exp. 5), the oocytes were harvested from follicular fluid after aspiration of follicles with a 20 gauge needle. Only oocytes with an intact, tightly adherent mass of corona radiata cells (intact oocytes) were selected for subsequent experiments. All oocytes were washed successively 3 times in the appropriate medium before culture. The collection of oocytes and preparation of cultures routinely was completed within 1.5 and $2 \mathrm{~h}$, respectively.

\section{Collection of membrana granulosa cells and follicular fluid}

Membrana granulosa cells and follicular fluid routinely were collected as described by Channing \& Ledwitz-Rigby (1975). Ovaries containing suitably-sized follicles were washed in BMOC-2A medium, placed on sterile gauze under a stereomicroscope and the follicles were aspirated aseptically using a 20 gauge needle. Care was taken to avoid puncturing surface capillaries. Follicular aspirates were pooled into sterile tubes (Falcon Plastics $15 \times 75 \mathrm{~mm}$; No. 2058), centrifuged at $2000 \mathrm{~g}$ for $15 \mathrm{~min}$ and the supernatant (follicular fluid) was removed aseptically to a fresh tube. The pellet (membrana granulosa cells) was re-suspended in culture medium, washed, re-centrifuged, and re-suspended in $1.0 \mathrm{ml}$ medium. Cell density was determined with a haemocytometer (Hanks \& Wallace, 1958) and cell viability was assessed using the trypan blue exclusion test (Merchant, Kahn \& Murphy, 1961).

In one series of experiments (Exp. 3), membrana granulosa cells were harvested using a validated harvesting procedure for improved cellular integrity (Campbell, 1979). Slices of ovaries were placed in Medium 199 plus Hepes buffer $\left(\mathrm{M}-199^{*} \mathrm{H}\right)$ containing 6.8 mM-ethyleneglycol-bis- $\beta$-aminoethyl ether- $N, N^{\prime}$-tetracetic acid (EGTA) and $0 \cdot 2 \%$ bovine serum albumin (BSA, Fraction V; Sigma) and were punctured vigorously using a sterile 18 gauge needle. The punctured follicles were then incubated for $15 \mathrm{~min}$ at $37^{\circ} \mathrm{C}$ under $5 \% \mathrm{CO}_{2}$ in humidified air, 
centrifuged at $100 \mathrm{~g}$ for $5 \mathrm{~min}$, re-suspended in a hypertonic sucrose solution $(0.5 \mathrm{M}$-sucrose, $0.2 \% \mathrm{BSA}$ and $1.8 \mathrm{mM}-\mathrm{EGTA}$ in M-199* $\mathrm{H}$ ) and incubated for an additional $10 \mathrm{~min}$. After the incubation in sucrose, the solution was diluted with 3 volumes of $\mathrm{M}-199^{*} \mathrm{H}$, follicles were aspirated and the aspirate was centrifuged at $2000 \mathrm{~g}$ for $15 \mathrm{~min}$. The granulosa cell pellet was re-suspended in culture medium, washed, re-centrifuged and re-suspended in $1.0 \mathrm{ml}$ medium. Cell density and viability determinations were carried out as described above.

\section{Culture procedures}

Cultures were maintained in wells of Lab-Tek chamber slides (No. 4838) in $0.4 \mathrm{ml}$ medium under $5 \% \mathrm{CO}_{2}$ in humidified air in a sealed desiccator at $37^{\circ} \mathrm{C}$ for $24 \mathrm{~h}$. The complex medium of Tsafriri \& Channing (1975a) was used. This medium (TCM) consisted of Medium 199 with Earle's salts and $12 \mathrm{~mm}$-Hepes buffer supplemented with $15 \%$ pig serum, $1 \mathrm{~mm}$-glutamine, 2.5 mM-lactate, $0.03 \mathrm{~mm}$-pyruvate, $12.5 \mathrm{mU}$ insulin $/ \mathrm{ml}$ and $50 \mu \mathrm{g}$ gentamicin $/ \mathrm{ml}$. Stock solutions $(\times 1000)$ of insulin and sodium pyruvate were prepared in Medium 199, divided into appropriate aliquots and stored frozen at $-20^{\circ} \mathrm{C}$. The serum was likewise stored in suitable aliquots. Media were made up routinely the evening before an experiment. In Exps 4 and 5, oocytes were cultured in neat, freshly prepared follicular fluid. In those cultures with membrana granulosa cells, the culture wells contained $0.3 \mathrm{ml}$ TCM and $0.1 \mathrm{ml}$ granulosa cell preparation; the final concentration of membrana granulosa cells was $5 \times 10^{6}$ viable cells $/ \mathrm{ml}$. All media were equilibrated to culture conditions for at least $2 \mathrm{~h}$ before use. Groups of 10-15 oocytes were cultured in each treatment, and each experiment was normally repeated at least 3 times. After culture, all oocytes were denuded, air-dried as described previously (McGaughey \& Polge, 1971 ), and stained with $0.29 \%(\mathrm{w} / \mathrm{v})$ Wright's stain in $2.9 \%(\mathrm{v} / \mathrm{v})$ glycerol and $97.1 \%$ methanol. Oocyte maturation was scored as reported previously (McGaughey, 1977a, 1978). Viability tests were carried out on membrana granulosa cells and cumulus cell masses.

\section{Statistical analyses}

Meiotic maturation of examined oocytes was classified as follows: (1) those that had remained at the germinal vesicle (GV) stage (immature), and (2) those that had developed beyond the $\mathrm{Gv}$ stage (diakinesis to metaphase II). The first classification was subdivided into (i) the proportion of GVs that were degenerate as defined by McGaughey, Montgomery \& Richter (1979), and (ii) the proportion of GVs that were normal (fibrous or diffuse; McGaughey et al., 1979). The second classification was subdivided into (i) the proportion of oocytes which reached metaphase I, and (ii) the proportion of oocytes that reached metaphase II. For each culture well, the proportions of oocytes in each of the above classifications were transformed to angles and analysed by the Duncan Multiple Range Test using the SPSS computer program (Nie, Hull, Jenkins, Steinbrenner \& Brent, 1975; McGaughey, 1978). Significant differences among experimental and control groups were approximated at $\alpha=0 \cdot 05$. Group means and their $95 \%$ confidence intervals were transformed back to percentages for tabulation. The Duncan Multiple Range Test has been used because, in comparison to other statistical tests, it employs decreasing significant differences and protection levels based on degrees of freedom (Duncan, 1955).

\section{Results}

\section{Series 1}

This experiment was carried out to assess the effect on maturation of co-culturing membrana granulosa cells with intact, liberated oocytes. The oocytes were harvested and incubated for approximately $2 \mathrm{~h}$ during collection and preparation of the membrana granulosa cells. In 5 
experiments, membrana granulosa cells did not significantly arrest maturation of intact, liberated oocytes. On the contrary, there was a significant stimulation of maturation of oocytes co-cultured with granulosa cells compared with that of oocytes cultured alone (Table 1). There was no significant difference detected between the proportion of matured co-cultured oocytes that had reached anaphase I to metaphase II compared with that of oocytes maintained alone (Category II). The mean viabilities of the membrana granulosa cells at harvesting and at the end of culture were $55 \%$ (range $39-74 \%$ ) and $47 \%$ (range 36-79\%), respectively $(n=10)$. The average mitotic index (number of live cells present after culture divided by the number of live cells present at the start of culture) was $0 \cdot 86$.

Table 1. The effect of membrana granulosa cells on the maturation of liberated, intact pig oocytes that were pre-cultured alone for $2 \mathrm{~h}$

\begin{tabular}{|c|c|c|c|}
\hline \multirow[b]{2}{*}{ Culture } & \multirow[b]{2}{*}{$\begin{array}{l}\text { No. of } \\
\text { oocytes }\end{array}$} & \multicolumn{2}{|c|}{ Mean $\%$ of oocytes which matured } \\
\hline & & $\begin{array}{c}\text { Category I } \\
\text { (diakinesis to } \mathrm{MII} \text { ) }\end{array}$ & $\begin{array}{c}\text { Category } \mathrm{II}+ \\
\text { (anaphase I to MII) }\end{array}$ \\
\hline $\begin{array}{l}\text { Oocytes } \\
\text { Oocytes + membrana } \\
\quad \text { granulosa cells* }\end{array}$ & $\begin{array}{l}159 \\
154\end{array}$ & $\begin{array}{l}64 \cdot 1(54 \cdot 8-72 \cdot 8)^{\mathrm{a}} \\
77 \cdot 0(71 \cdot 6-82 \cdot 0)^{\mathrm{b}}\end{array}$ & $\begin{array}{l}72.8(43.8-81.4)^{A} \\
67.5(44.9-78.3)^{A}\end{array}$ \\
\hline $\begin{array}{l}* 5.0 \times 10^{6} \text { viable ce } \\
\dagger \% \text { of oocytes cultu } \\
\neq \% \text { of oocytes in C } \\
\text { Figures in parenthes } \\
\text { Groups with differen }\end{array}$ & $\begin{array}{l}\text { ml. } \\
\text { ory I. } \\
\text { re the } 9 \\
\text { perscrip }\end{array}$ & $\begin{array}{l}\text { confidence interval } \\
\text { are significantly diff }\end{array}$ & $\begin{array}{l}\text { s for the means. } \\
\text { erent, } \alpha=0.05 \text {. }\end{array}$ \\
\hline
\end{tabular}

Series 2

This series was performed to determine whether it was necessary to expose liberated oocytes directly to membrana granulosa cells for the somatic cells to exert a regulatory effect on maturation. Culture wells containing the membrana granulosa cell suspension were therefore prepared before collection of the oocytes. Liberated oocytes were transferred to these wells within $20 \mathrm{~min}$ of release from their follicular environment. No significant effect on maturation was exerted by the membrana granulosa cells when the oocytes were co-cultured directly with these cells ( 74 and $78 \%$ matured when cultured alone and with membrana granulosa cells, respectively; $n=63$ and 69 , respectively). In subsequent experiments, the oocytes were collected and preincubated during the preparation of the membrana granulosa cell suspension.

\section{Series 3}

Oocytes were co-cultured with membrana granulosa cells harvested by a technique for improved cellular integrity (Campbell, 1979). There was no significant effect on the regulatory capacity of membrana granulosa cells by the harvesting procedure utilized. The maturation of oocytes co-cultured with membrana granulosa that had been directly aspirated from the follicles was not significantly different from that of oocytes exposed to membrana granulosa cells that had been harvested from follicles in ovaries incubated in EGTA-sucrose media ( 74 and $79 \%$ matured, respectively; $n=86$ and 80 , respectively). The mean viabilities at harvesting and at the end of culture of the membrana granulosa cells obtained from incubated follicles were $61 \%$ (range $44-70 \%$ ) and $56 \%$ (range $42-68 \%$ ), respectively $(n=8)$. The average mitotic index of the cells was 0.84 . 


\section{Series 4}

The effect of follicular fluid on the incidence of maturation of intact, liberated oocytes was assessed. Culture wells containing $100 \%$ follicular fluid were prepared and equilibrated to culture conditions for at least $2 \mathrm{~h}$ before the oocytes were added to the system. The oocytes were collected in BMOC-2A and washed successively three times in follicular fluid before culture. Freshly prepared neat follicular fluid did not significantly affect the incidence of maturation of intact oocytes (Category I; Table 2). Furthermore, there was no significant difference detected between the two groups in the proportion of matured oocytes that reached anaphase I to metaphase II (Category II).

Table 2. The effect of follicular fluid on the maturation of intact, liberated pig oocytes

\begin{tabular}{lccc}
\hline & \multicolumn{2}{c}{ Mean \% of oocytes which matured } \\
\cline { 3 - 4 } Culture medium & $\begin{array}{c}\text { No. of } \\
\text { oocytes }\end{array}$ & $\begin{array}{c}\text { Category I* } \\
\text { (diakinesis to MII) }\end{array}$ & $\begin{array}{c}\text { Category II } \\
\text { (anaphase I to MII) }\end{array}$ \\
\hline TCM & 78 & $78 \cdot 3(60 \cdot 4-89 \cdot 8)^{\mathrm{a}}$ & $65 \cdot 5(48 \cdot 8-71 \cdot 0)^{\mathrm{A}}$ \\
$100 \%$ follicular fluid & 74 & $73 \cdot 8(66 \cdot 8-77 \cdot 3)^{\mathrm{a}}$ & $74.0(58 \cdot 3-82 \cdot 1)^{\wedge}$ \\
\hline
\end{tabular}

$* \%$ of oocytes cultured.

$\dagger \%$ of oocytes in Category 1 .

Figures in parentheses are the $95 \%$ confidence intervals for the means.

Groups with different superscripts are significantly different, $\alpha=0.05$.

\section{Series 5}

To determine whether there was a requirement for continual exposure of oocytes to their follicular environment for maturation to be inhibited by follicular fluid, oocytes collected from aspirated follicles were washed successively 3 times in follicular fluid before culture. In 2 experiments, involving 4 replicates for each treatment group, exposure of oocytes to medium before culture in follicular fluid did not significantly affect the incidence of maturation compared with that of oocytes exposed continuously to the follicular environment (81 and $73 \%$ matured, respectively).

\section{Discussion}

The data presented in this paper clearly demonstrate that neither follicular fluid nor membrana granulosa cells exerted an inhibitory effect on the maturation of liberated, intact pig oocytes. This lack of inhibition was not due to an irreversible release of the oocytes from meiotic arrest during collection or to a loss of viability of the granulosa cells during culture. These results, therefore, question the presence in follicular fluid of a stable OMI, and substantiate a growing body of literature which raises doubt as to the applicability of such an oocyte-membrana granulosa cell co-culture system for investigation of the mechanisms which regulate meiotic maturation.

The lack of any demonstrable inhibitory effect of pure follicular fluid is surprising in view of the observations of others (reviewed by Channing et al., 1980) that follicular fluid at a concentration of $50 \%$ exhibited partial inhibitory activity. The results obtained in this study cannot be accounted for by an irreversible release from meiotic arrest since those oocytes exposed continuously to the follicular environment nevertheless underwent maturation (Exp. 5). 
Furthermore, in the previous studies, any change in the steroidal balance of the follicular fluid caused by sterilization through a Millipore filter was unlikely responsible for the inhibitory activity; charcoal-extracted follicular fluid still possessed its inhibitory properties after more than $99 \%$ of progesterone and oestrogen were removed (Tsafriri \& Channing, 1975a).

The dramatic dissimilarities between the results of the co-culture study reported here and those obtained by Tsafriri \& Channing (1975a) are difficult to explain in view of exact duplication of experimental procedures. A detrimental agent or unfavourable condition that were absent in the present experiments may have been introduced in the previous study. Additionally, it is possible that oocytes were damaged by products from non-viable granulosa cells; neither the viability of the granulosa cells in vitro nor the reversibility of the inhibitory action of these somatic cells on maturation was assessed by Tsafriri \& Channing (1975a). This explanation could also account for lack of demonstrable inhibitory activity of rat membrana granulosa cells unless these cells have been pre-cultured for $24 \mathrm{~h}$ before the addition of oocytes (Tsafriri, 1978).

An alternative explanation for the observed differences between the results reported here and those of others may relate to the end-point of the bioassay employed. In our study, meiotic maturation was determined from cytogenetic analysis of well-spread, analysable chromatin configurations. Examination of fixed whole-mounts of cultured oocytes, as carried out by Tsafriri \& Channing (1975a), might well have led to misclassification of meiotic stages. In our experience, the considerable yolk in the pig oocyte makes it extremely difficult to determine accurately the meiotic stage by the whole mount technique, the conformation of the GV appearing quite similar to that of the diploid metaphase II configuration (diploid MII) and the pronucleus. We present, therefore, the following explanation to account for the inconsistencies in the reported data. In a group of oocytes cultured for $24 \mathrm{~h}, 62 \%$ of matured oocytes ( $77 \%$ of the total number of oocytes cultured) will have reached anaphase I to metaphase II, of which $40 \%$ are diploid MII (i.e. 25\% of total cultured oocytes are diploid MII; unpublished observation). During a subsequent $24 \mathrm{~h}$ culture period, metaphase II oocytes will either degenerate or undergo activation to exhibit diploid pronuclei. We propose that degenerate diploid MIIs and diploid PNs might be misclassified as GVs, resulting in a considerable underestimation of the overall incidence of maturation. This error might be magnified by the additional misclassification of degenerate metaphase I and possibly, diakinesis configurations, after $48 \mathrm{~h}$ of culture, the interval used by Tsafriri \& Channing (1975a). The reported 'inhibitory' actions of follicular fluid or granulosa cells can therefore be accounted for by proposing that these follicular components increased the incidence of degeneration in maturing or matured oocytes which, in turn, resulted in misclassification of meiotic stage.

The results of this study indicate that co-culture of oocytes with membrana granulosa cells does not provide an appropriate system for investigation of the regulatory mechanisms involved in meiotic maturation; for a system to have potential use for such investigations, the inhibition of maturation obtained should be consistent and almost absolute. The co-culture of liberated oocytes on follicular hemisections provides such a system. Under these conditions, maturation has been found, consistently, to be inhibited (Foote \& Thibault, 1969; Tsafriri \& Channing, 1975a; Sato \& Ishibashi, 1977; Tsafriri, 1978; Leibfried \& First, 1980b), suggesting a requirement for both thecal and granulosa layers for the inhibitory action to be realized. Since the steroidal composition of follicular fluid is regulated through the cooperation of these two ovarian layers (reviewed by Richards, 1979), it is possible that steroids mediated the observed inhibitory actions of follicular hemisections. It is well established that granulosa cells have limited, if any, ability to synthesize $\mathrm{C}_{19}$ steroids (reviewed by Armstrong, Goff \& Dorrington, 1979), and that oestradiol synthesis by these cells is dependent upon the availability of theca-derived androgen (reviewed by Richards, 1979). Co-culture of oocytes with both follicular components might, therefore, have resulted in the maintenance of an oestrogen:progesterone environment characteristic of that of the immature follicle. In support of this suggestion it has been shown that intact pig oocytes are maintained in meiotic arrest in vitro provided that the 
steroidogenic output of the cumulus cells results in an oestradiol:progesterone of approximately $0 \cdot 1$, but that maturation occurs when this ratio is reduced to approximately 0.01 (C. Racowsky, unpublished observation). Investigations are currently in progress to determine the regulatory mechanisms which mediate this steroidogenic control.

We thank Robin Hendricks for excellent technical assistance, Tanya Francis for typing the manuscript, and Cudahy Foods of Phoenix, Arizona for supplying the pig reproductive tracts. This study was supported by a grant from the Whitehall Foundation and by Grant HD06532.

\section{References}

Armstrong, D.T., Goff, A.F. \& Dorrington, J.H. (1979) Regulation of follicular estrogen biosynthesis. In Ovarian Follicular Development and Function, pp. 169-181. Eds A. R. Midgley \& W. A. Sadler. Raven Press, New York.

Brinster, R.L. (1971) Measuring embryonic enzyme activities. In Methods in Mammalian Embryology, pp. 215-227. Ed. J. C. Daniel, Jr. W. H. Freeman \& Co., San Francisco.

Campbell, K.L. (1979) Ovarian granulosa cells isolated with EGTA and hypertonic sucrose: cellular integrity and function. Biol. Reprod. 21, 773-786.

Centola, G.M. \& Anderson, L.D. (1979) Porcine granulosa cells as a possible source of oocyte maturation inhibitor (OMI). Biol. Reprod. 20, suppl. 1, Abstr. 89.

Channing, C.P. \& Ledwitz-Rigby, F. (1975) Methods for assessing hormone-mediated differentiation of ovarian cells in culture and in short-term incubations. In Methods and Enzymology, pp. 183-230. Eds J. G. Hardman \& B. W. O'Malley. Academic Press, New York.

Channing, C.P., Schaerf, F.W., Anderson, L.D. \& Tsafriri, A. (1980) Ovarian follicular and luteal physiology. Int. Rev. Physiol. 22, 117-201.

Cho, W.K., Stern, S. \& Biggers, J.D. (1974) Inhibitory effect of dibutyryl cAMP on mouse oocyte maturation in vitro. J. exp. Zool. 187, 383-386.

Dekel, N. \& Beers, W.H. (1978) Rat oocyte maturation in vitro; relief of cyclic AMP inhibition by gonadotropins. Proc. natn. Acad. Sci. U.S.A. 75, 43694373.

Duncan, D.B. (1955) Multiple range and multiple ' $F$ ' tests. Biometrics II, 1-42.

Foote, W.D. \& Thibault, C. (1969) Recherches experimentales sur la maturation in vitro des ovocytes de truie et de veau. Annls Biol. anim. Biochim. Biophys. 9, 329-349.

Hanks, J.H. \& Wallace, J.H. (1958) Determination of cell viability. Proc. Soc. exp. Biol. Med. 98, 188-192.

Jagiello, G., Graffeo, J., Ducayen, M. \& Prosser, R. (1977) Further studies of inhibitors of in vitro mammalian oocyte maturation. Fert. Steril. 28. 476-481.

Leibfried, L. \& First, N.L. (1980a) Effect of bovine and porcine follicular fluid and granulosa cells on maturation of oocytes in vitro. Biol. Reprod. 23, 699-704.

Leibfried, L. \& First, N.L. (1980b) Follicular control of meiosis in the porcine oocyte. Biol. Reprod. 23, $705-709$.
Mc Gaughey, R.W. (1977a) The culture of pig oocytes in minimal medium, and the influence of progesterone and estradiol-17 $\beta$ on meiotic maturation. Endocrinology 100, 39-45.

McGaughey, R.W. (1977b) The maturation of porcine oocytes in minimal defined culture media with varied macromolecular supplements and varied osmolarity. Expl Cell Res. 109, 25-30.

McGaughey, R.W. (1978) In vitro oocyte maturation. In Methods in Mammalian Reproduction, pp. 1-20. Ed. J. C. Daniel, Jr. Academic Press, New York.

McGaughey, R.W. \& Polge, C. (1971) Cytogenetic analysis of pig oocytes matured in vitro.J. exp. Zool. 176, 383-391.

McGaughey, R.W., Montgomery, D.H. \& Richter, J.D. (1979) Germinal vesicle configurations and patterns of polypeptide synthesis of porcine oocytes from antral follicles of different size, as related to their competency for spontaneous maturation. $J$. exp. Zool. 209, 239-253.

Merchant, D.J., Kahn, R.H. \& Murphy, W.H. (1961) Handbook of Cell and Organ Culture. Burgess Publ. Co., Minneapolis.

Nekola, M.V. \& Smith, D.M. (1974) Oocyte maturation and follicle cell viability in vitro. Eur. J. Obstet. Gynec. Reprod. Biol. Suppl. 4, S125-\$131.

Nie, N., Hull, C., Jenkins, J., Steinbrenner, K. \& Brent, D. (1975) Statistical Package for the Social Sciences, 2nd edn, p. 422. McGraw-Hill, New York.

Pincus, G. \& Enzmann, E.V. (1935) The comparative behaviour of mammalian eggs in vivo and in vitro. $J$. exp. Med. 62, 665-675.

Rice, C. \& McGaughey, R.W. (1980) Interactions between the granulosa cell and the oocyte in vitro. $J$. Anim. Sci. 51 , Suppl. Abstr. 521.

Rice, C. \& MeGaughey, R.W. (1981) Effect of testosterone and dibutyryl cAMP on the spontaneous maturation of pig oocytes. J. Reprod. Fert. 62 . 245-256.

Richards, J.S. (1979) Hormone regulation of hormone receptors in ovarian follicular development. In Ovarian Follicular Development and Function, pp. 225-242. Eds A. R. Midgeley \& W. A. Sadler. Raven Press, New York.

Richter, J.D. \& McGaughey, R.W. (1979) Specificity of inhibition by steroids of porcine oocyte maturation in vitro. J. exp. Zool. 209, 81-90.

Sato, E. \& Ishibashi, T. (1977) Meiotic arresting action of the substance obtained from cell surface of porcine granulosa cells. Jap. J. Zootech. Sci. 48, 22-26. 
Sreenan, J. (1970) In vitro maturation and attempted fertilization of cattle follicular oocytes. J. agric. Sci., Camb. 75, 393-396.

Stone, S.L., Pomerantz, S.E., Schwartz-Kripner, A. \& Channing, C.P. (1978) Inhibitor of oocyte maturation from porcine follicular fluid: further purification and evidence for reversible action. Biol. Reprod. 19, 585-592.

Tsafriri, A. (1978) Inhibition of nuclear maturation of isolated rat oocytes by follicular constituents. Annls Biol. anim. Biochim. Biophys. 18, 523-526.

Tsafriri, A. (1979) Oocyte maturation in mammals. In The Vertebrate Ovary, pp. 409-442. Ed. E. Jones. Plenum Press, New York.

Tsafriri, A. \& Channing, C.P. (1975a) An inhibitory influence of granulosa cells and follicular fluid upon porcine oocyte meiosis in vitro. Endocrinology 96, 922-927.
Tsafriri, A. \& Channing, C.P. (1975b) Influence of follicular maturation and culture conditions on the meiosis of pig oocytes in vitro. J. Reprod. Fert. 43, $149-152$.

Tsafriri, A., Pomerantz, S.H. \& Channing, C.P. (1976a) Inhibition of oocyte maturation by porcine follicular fluid: partial characterization of the inhibitor. Biol. Reprod. 14, 511-516.

Tsafriri, A., Pomerantz, S.H. \& Channing, C.P. (1976b) Follicular control of oocyte maturation. In Ovulation in the Human, pp. 31-39. Academic Press, New York.

Tsafriri, A., Channing, C.P., Pomerantz, S.H. \& Lindner, H.R. (1977) Inhibition of maturation of isolated rat oocytes by porcine follicular fluid. J. Endocr. 75, $285-291$.

Received 25 January 1982 